\title{
Nová perspektiva DSB?
}

\author{
Iva Heribanová
}

Divadelni svět Brno 2021: Nová perspektiva. Národní divadlo Brno. 20.-25. května 2021. Program v divadlech a online.

Poté, co festival Divadelní svět Brno (DSB) podtitulem pro rok 2020 „Nic se neděje“ nevědomě předpověděl realitu svou i ostatních živých kulturních produkcí po drtivou většinu následujícího roku, byl ročník 2021 zastřešen tématem „Nová perspektiva“. Tedy především otázkou, jakou novou perspektivu pandemie přinesla a jak promění budoucí kulturní život. Na první pohled nejvýraznějším (nutným) novem bylo přemístění části programu, především zahraničních produkcí, do online prostředí. $\mathrm{V}$ případě živých představení nebylo takřka do poslední chvíle jisté, zda proběhnou. Nakonec však DSB získal výjimku z aktuálních vládních opatření, a tak v šesti květnových dnech nabídl obvyklou programovou dávku o téměř šedesáti položkách.

$\mathrm{Z}$ neuskutečněného loňského ročníku byla do letošního přenesena ve výhradně online podobě antická sekce dedikovaná teatroložce a klasické filoložce Evě Stehlíkové a herci a režisérovi Františku Derflerovi. Její jádro tvořila videoscénická skica Senekova Oidipa, scénické čtení z dosud neuvedeného Stehlíkové prvního českého překladu této tragédie, natočené na sklepní scéně Centra experimentálního divadla, kde působilo Derflerovo Divadlo U stolu. Ještě výraznější pocty se jim dostalo v doprovodném pořadu Antická anketa, v němž pětice respondentů hovořila o Stehlíkové, Derflerovi, Divadle U stolu a Senekovi.
Díky vhodně zvolené formě ankety vznikl svižný, stručný, avšak informačně nabitý hodnotný portrét. Původní pořady doplnily $\mathrm{v}$ antické lince záznamy tří zahraničních inscenací. Jednou z nich byla Médea mad’arského souboru KV Társulat - Trafó, zasazená do prostředí ženské skupinové terapie, při níž se uplatňují metody psychodramatu. Původní Euripidův text zde zní pouze v momentech přehrávání konfliktů ženy, která v Budapešti ve 21. století zažívá stejné odvržení otcem svých dětí jako Médea v antickém mýtu. $\mathrm{V}$ průběhu sezení odhaluje terapeutce a dalším dvěma klientkám podrobnosti své situace a s jejich pomocí vstupuje do hypotetických dialogů s partnerem i jeho budoucím tchánem. Scény, jež propojují tyto přímé citace z Euripidovy tragédie, rozvíjí témata předlohy. Terapeutka zaujímá při psychodramatu roli krále Kreonta, zatímco má sama autoritativní zpo̊sob vystupování a možná až despotické sklony. Žena stávající se Iásónem se terapie účastní proto, že kvůli osobnímu prospěchu opustila manžela a děti. A poslední klientka cítí potřebu zprostředkovat možný pohled Médeiných dětí na celou situaci, nebot je těhotná. Všechny tři ženy navíc na Médeu neustále pohlíží jako na pomateného vetřelce. Vzniká tak důsledná aktualizace antické látky, schopná zaujmout i ze záznamu.

Druhou linkou z minulého ročníku byl profil režiséra Jana Kačeny, prezentovaný 
taktéž pouze online. Speciálně pro DSB vznikly záznamy dvou Kačenových inscenací z pražského A studia Rubín (stojim ve tmě abych viděl světlo dělám zlo aby dobro kvetlo MIRIAM a Traktát o stepním vlku (Autodráha)) a půlhodinový dokumentární portrét Hovory z Ján (na okraj divadelni tvorby Jana Kačeny). V režii Robina Kvapila se v dokumentu skládá portrét Kačeny-režiséra podobným zpo̊sobem, jakým sám tvořil: Kačenova práce je ve snímku pojmenovaná teatrologem Martinem Pšeničkou jako „uvažování divadlem“, dokument samotný uvažuje filmem. Výpovědi a debaty teatrologů i režisérových spolupracovníků v něm doplňují záběry z Kačenových inscenací nikoli s cílem podat jasnou a přehlednou zprávu o jeho osobnosti a díle, ale spíše nabídnout podněty $\mathrm{k}$ uvažování o jeho tvorbě $\mathrm{v}$ kontextu současného českého i světového divadla.

Novinkami programové skladby byly dvě debaty, v nichž vybraní divadelníci diskutovali nové perspektivy své tvorby i kultury obecně. Poprvé byly do programu zařazeny také koprodukční inscenace vytvořené nezávislými soubory přímo pro DSB. Z plánovaných šesti byly nakonec uvedeny pouze dvě: Druzi Lidé Divadla X10 a Hilsner a ti druzi Divadla Feste. Inscenace režiséra Jiřího Honzírka, na níž se koprodukčně podílel také Meeting Brno, zpracovává téma Hilsneriády, avšak nahlíží na něj z nové perspektivy, pohledem údajných Hilsnerových obětí.

Stejně jako $\mathrm{v}$ předchozích ročnících zahrnoval program přehlídku inscenací pořadatelských scén. Mezi nimi byly navíc i tři premiéry kvůli uzavření divadel různě dlouho odkládané: v Národním divadle Brno Kunderovi Majitelé klićů a Doktorka Roberta Ickea, v Divadle Husa na provázku Setkáni spiklenců, inscenace Petra
Erbese a Borise Jedináka reagující na fenomén konspiračních teorií. Vedle těchto „domácích“ premiér a zmíněných koprodukčních projektů byla na festivalu taktéž poprvé uvedena nová inscenace Divadelního spolku JEDL Manželská historie, která se stala symbolickou oslavou desetiletého výročí spolku a třicetileté spolupráce trojice Nebeský-Trmíková-Prachař.

Tradičně byla součástí festivalu také sekce tanečního a pohybového divadla. Jejím prvním představením a zároveň slavnostním otevřením celého festivalu při západu slunce na piazzettě Janáčkova divadla byla Noosféra neboli zmrzlinové andante pro tanećniky a fontánu, koprodukční site-specific projekt DSB a Baletu NdB na živě interpretovanou hudbu Františka Chaloupky. Hostující pohybová představení se nesla v duchu ohromujících fyzických výkonů, at’ už šlo o Amazonky Lenky Vagnerové \& Company, HEROES Losers Cirque Company nebo záznam If At All izraelského souboru Kibbutz Contemporary Dance Company. V kontrastu k nim stála intimnější inscenace Hic Sunt Dracones Divadla Continuo, vizuální báseň zkoumající iluzivní možnosti využití ženského těla (nikoli v sexuální, nýbrž spíše fantazijní, surreální rovině). Těla čtyř performerek se v ní za živého hudebního doprovodu rozkládají na jednotlivé části a opět skládají do podoby různých fantaskních tvorů. Oslňující iluzivnost, lehkost pohybů a artistnost prvků jsou prokládány odlehčenou komičností.

Specifickou dramaturgickou linku, v podstatě festival ve festivalu, tvořila již poněkolikáté představení pro dětské diváky. Ta, s výjimkou Demokracie Divadla Minor, zaplnila po dva víkendové dny nejprve zahradu u Divadla Polárka a posléze, vlivem nepř́iliš májového počasí, také jeho sál. Na rozdíl od ostatních festivalových 
sekcí se program věnovaný dětem důsledně odehrával zcela mimo online prostor, nejvýrazněji v interaktivní procházce $K u d y$ vede cesta?, připravené Divadlem Polárka ve spolupráci s Divadlem Lampion, Jihočeským divadlem a Divadlem Drak. Během sobotního a nedělního odpoledne se na ni mohly vydávat skupiny s dětmi, na které v blízkosti osmi festivalových scén čekala zastavení s úkoly podněcujícími kreativní činnost. Inspirací pro úkoly byli fiktivní průvodci, „dětská já“ významných osobností spojených s danými divadly (např. Mozart, Edison nebo bratři Mrštíkové). Kromě vykonání cesty fyzické totiž procházka vybízela $\mathrm{k}$ uvažování nad cestou budoucím životem a tím, kdo nebo co má moc přání a sny o budoucnosti vyplnit. Na ty, kdo interaktivní procházku dokončili, čekala odpověd' v zrcadle na posledním zastavení v Divadle Polárka.

Samotné téma nových perspektiv se promítlo do letošního ročníku DSB - z něhož byla část určena už pro minulý rok - jen v určitých momentech. Jedním z nejzásadnějších byl záznam Tři sester režisérky Susanne Kennedy z Münchner Kammerspiele, inscenace představující nejradikálnější novou divadelní perspektivu. Základní téma Čechovovy hry, ustrnutí na místě a neschopnost se ze své situace vymanit, Kennedy posouvá do současného lapení ve virtuálním prostředí ústícího do odcizení od reálných životů. Z Čechovova textu se stává pouhé torzo útržků několika iko- nických replik, zaznívajících z nahrávky. Ty se navrací v repetitivních výjevech v jakémsi bezčasí, kde se smazává rozdíl mezi herci a loutkami, fyzičností a projekcí.

Divadelní svět Brno 2021 byl po mnoha měsících vůbec první příležitostí $\mathrm{k}$ živému setkání s divadlem, hojně využitou navzdory potřebným hygienickým opatřením. Ta byla - alespoň na představeních, která jsem navštívila - dodržována vesměs ochotně, přestože místy docházelo ke zmatení a nejistotě při jejich výkladu (ostatně přepočítávání hodin platnosti konkrétního typu testu bylo pro mnohé stálicí i v následujících týdnech). Festival tak ukázal, že je divadlo nadále žádané a schopné provozu i za ztížených podmínek. Mimo to přenos některých položek programu do online prostředí, jistě vnímaný jako handicap, paradoxně nabídl něco, co možná v minulosti DSB scházelo. Živá představení se sice i letos odehrávala převážně simultánně ve večerních hodinách, avšak online program byl dostupný bud' během celého festivalu, nebo po dobu 24 hodin. Na rozdíl od předchozích ročníků tak bylo v lidských silách zhlédnout větší část programu. Ten byl sice stále velmi obsáhlým, ale jako celek se zbavoval puncu série hostujících představení, nabýval na festivalové atmosféře. DSB dal divákům možnost ponořit se do výjimečné nálady v průběhu celého svého trvání - odpoledne, večer, pozdě v noci nebo i ráno u snídaně. Snad se tato tendence udrží do budoucna. 